\title{
Impacts of otter trawling on colonial epifaunal assemblages on a cobble bottom ecosystem on Western Bank (northwest Atlantic)
}

\author{
Lea-Anne Henry ${ }^{1,4}$, Ellen L. R. Kenchington ${ }^{2, *}$, Trevor J. Kenchington ${ }^{2,3}$, \\ Kevin G. MacIsaac ${ }^{2}$, Cynthia Bourbonnais-Boyce ${ }^{2}$, Donald C. Gordon Jr. ${ }^{2}$ \\ ${ }^{1}$ Department of Biology, Dalhousie University, 1355 Oxford Street, Halifax, Nova Scotia B3H 4J1, Canada \\ ${ }^{2}$ Bedford Institute of Oceanography, Department of Fisheries and Oceans, 1 Challenger Drive, Dartmouth, \\ Nova Scotia B2Y 4A2, Canada \\ ${ }^{3}$ Gadus Associates, RR\#1 Musquodoboit Harbour, Nova Scotia B0J 2L0, Canada
}

${ }^{4}$ Present address: Scottish Association for Marine Science, Dunstaffnage Marine Laboratory, Oban, Argyll PA37 1QA, UK

\begin{abstract}
Colonial epifauna are an important component of benthic communities, providing structural complexity at scales of millimetres to metres. Many are sessile, emergent and fragilecharacteristics which render them vulnerable to disturbances associated with bottom fishing. Many also have impressive abilities to rapidly regenerate both sexually and asexually and, consequently, the ultimate results of impacts of physical disturbance are difficult to predict. We analysed the effects of $3 \mathrm{yr}$ of pulsed experimental otter trawling, following an asymmetrical before-after-control-impact design, on grab-sampled colonial epifauna. Our study site was on a cobble seabed on the Scotian Shelf in a formerly important fishing ground which had seen no disturbance by mobile fishing gears for $10 \mathrm{yr}$. The number of taxa, total biomass, the biomass of component major taxa (hydroids, bryozoans, sponges, tunicates, soft corals) and the community composition were analysed for single-year and cumulative effects. The study site had a rich colonial fauna containing at least 53 taxa, the majority of which were hydroids. The small vase sponge Scypha ciliata, the leafy bryozoans Dendrobeania spp. and the hydroids Symplectoscyphus spp. were the most frequent, occurring in $>70 \%$ of the samples. Significant inter-annual differences at control sites were observed. The number of taxa, total biomass and hydroid biomass increased over the study period, with associated changes in community composition. Short-term effects of trawling were detected as decreases in the number of taxa per sample, total biomass and total hydroid biomass across the trawling events, although these trends were non-significant after Bonferroni adjustment. No cumulative effects from the pulsed trawling were detected, and colonial species assemblages on control and impacted lines were similar at the end of the experiment. While some of the tests for trawling effects were statistically weak, it is certain that any effects were small relative to natural inter-annual change.
\end{abstract}

KEY WORDS: Otter trawling · Colonial epifauna $\cdot$ Cobble seabed $\cdot$ Experiment Resale or republication not permitted without written consent of the publisher

\section{INTRODUCTION}

Colonial marine invertebrates are comprised of integrated morphological units, such as polyps or zooids, which can function autonomously for short periods of time (Gili \& Hughes 1995, Sanchez \& Lasker 2003). The sessile, emergent and often fragile growth forms of some benthic colonial species appear to make them particularly vulnerable to disturbances by bottom fishing activities, such as trawling and dredging (e.g. Van Dolah et al. 1987, Sainsbury et al. 1997, Koslow et al. 2001, Fosså et al. 2002, Hall-Spencer et al. 2002, Wassenberg et al. 2002). However, most colonial epifauna are capable of both sexual and asexual reproduction. Local dispersal, associated with either mode of reproduction in various species (e.g. the crawling 
planulae of many hydroid species and fragmentation of corals), can contribute to the formation of small-scale aggregations (Jackson 1986, Gili \& Hughes 1995, Goldson et al. 2001) that could be locally extirpated by bottom fishing. Alternatively, many species with longdistance dispersal mechanisms and rapid growth can opportunistically occupy primary space in early successional stages of benthic communities (e.g. Gili \& Hughes 1995, Pulfrich 1996, Orlov 1997), such as, potentially, in areas disturbed by bottom fishing. This diversity of colonial life-history strategies makes it difficult to predict the direction of change induced by the impacts of fishing gear, let alone its extent.

Bottom fishing has the potential to directly displace, injure, remove, or destroy colonies (e.g. Van Dolah et al. 1987, Sainsbury et al. 1997, Freese et al. 1999, Fosså et al. 2002, Wassenberg et al. 2002). Injuries, which may lead to delayed mortality (Freese 2003), demand costly resources for regeneration, potentially impairing colony growth and sexual reproduction (Rinkevich 1996, Henry \& Kenchington 2004a), and hence may ultimately limit population recruitment. However, mortality creates unoccupied space that may offer opportunities for colonial epifaunal recruitment and growth. In practice, high fishing intensities can reduce colonial epifaunal richness and biomass (Veale et al. 2000), and can be correlated with shifts in assemblages from those dominated by large, erect, rigid colonies to those with more flexible, runner-like, or encrusting growth forms (Pitcher et al. 2000, Bradshaw et al. 2001, Bremner et al. 2003, Henry \& Kenchington 2004b). Bottom fishing can also alter seabed physical characteristics, such as sediment properties (Schwinghamer et al. 1998, Kenchington et al. 2001), microtopography (Caddy 1973, Thrush et al. 1995, Currie \& Parry 1996, Schwinghamer et al. 1998) and substrate stability (Caddy 1973, Black \& Parry 1994, 1999, Freese et al. 1999), while resuspending sediments (Churchill 1989, Jennings \& Kaiser 1998). These physical characteristics affect recruitment and community structure of colonial epifauna (e.g. hydroids, Gili \& Hughes 1995); hence, their modification may also alter the species composition.

Understanding the impacts of fishing gears on benthic habitats and communities is a difficult and expensive undertaking, especially in offshore marine environments. While some useful information can be obtained from laboratory experiments, well-designed field programs are essential. Their design must be adapted to the considerable natural variability, both spatial and temporal, which is displayed by seabed habitats and communities. Observational studies, comparing areas with different fishing histories or over time in the same area, can provide indirect evidence of longer-term effects at the spatial scale of whole fishing grounds. In such studies, however, the conclusions will be equivocal, as natural fluctuations may be mistakenly attributed to human impacts, while it is difficult to accurately determine either the magnitude of the fishing disturbance or even the specific gear types involved, since fished areas often have histories of multiple gear usage. Alternatively, small-scale manipulative experiments can provide direct evidence of the immediate impacts of a known disturbance event on a particular habitat. In some cases, the prior disturbance history is known, such as when the study site is in an area closed to other fisheries. However, the very high cost of such experiments limits their spatial and temporal extent, as well as the intensity of the impact applied. Most often they have been confined to relatively shallow coastal areas, where wave-generated natural disturbances frequently affect the seabed, rather than in the deep offshore habitats typical of major trawling grounds. Understanding the seabed impacts of fishing gear therefore requires a combination of approaches, including the use of the largest scale, longest term, controlled, replicated, manipulative experiments that can be supported in closed portions of offshore fishing grounds.

Here, we examine the effects of annually repeated otter trawling on the assemblage structure (number of taxa, biomass and assemblage composition) of grabsampled colonial epifauna on a cobble bottom on Western Bank, a plateau on the Scotian Shelf (Fig. 1). The analyses are confined to colonial invertebrate taxa because of their unique biological traits and because, unlike non-colonial taxa, meaningful abundance data are not available, necessitating separate analyses. (The effects of the same experiment on non-colonial taxa will be addressed elsewhere). Whole-community or assemblage approaches to detecting impacts of bottom fishing sometimes miss differential responses between individual community components. Therefore, we also decomposed the total colonial epifaunal biomass into sponges, soft corals, hydroids, bryozoans and tunicates, to examine responses of each major taxon. Details of the catches in the experimental trawls have been reported by Kenchington et al. (2005).

Western Bank is one of the major fishing banks in the northwest Atlantic, with a fishing history chronicled back to the early 17 th century (Innes 1954). This area was trawled from before 1920, initially for haddock (McKenzie 1946, Wallace 1955) and subsequently for a variety of groundfish. Like much of the region, it was heavily fished from the 1960s by both Canadian and foreign vessels. In 1987, a large portion of Western Bank, referred to as the '4TVW Haddock Nursery Area' or 'Haddock Box', was closed to groundfish fishing. It was subsequently opened to demersal longlining for a few years, but has been closed to all groundfish gears since 1993. The box remains open to scallop fishing, but 


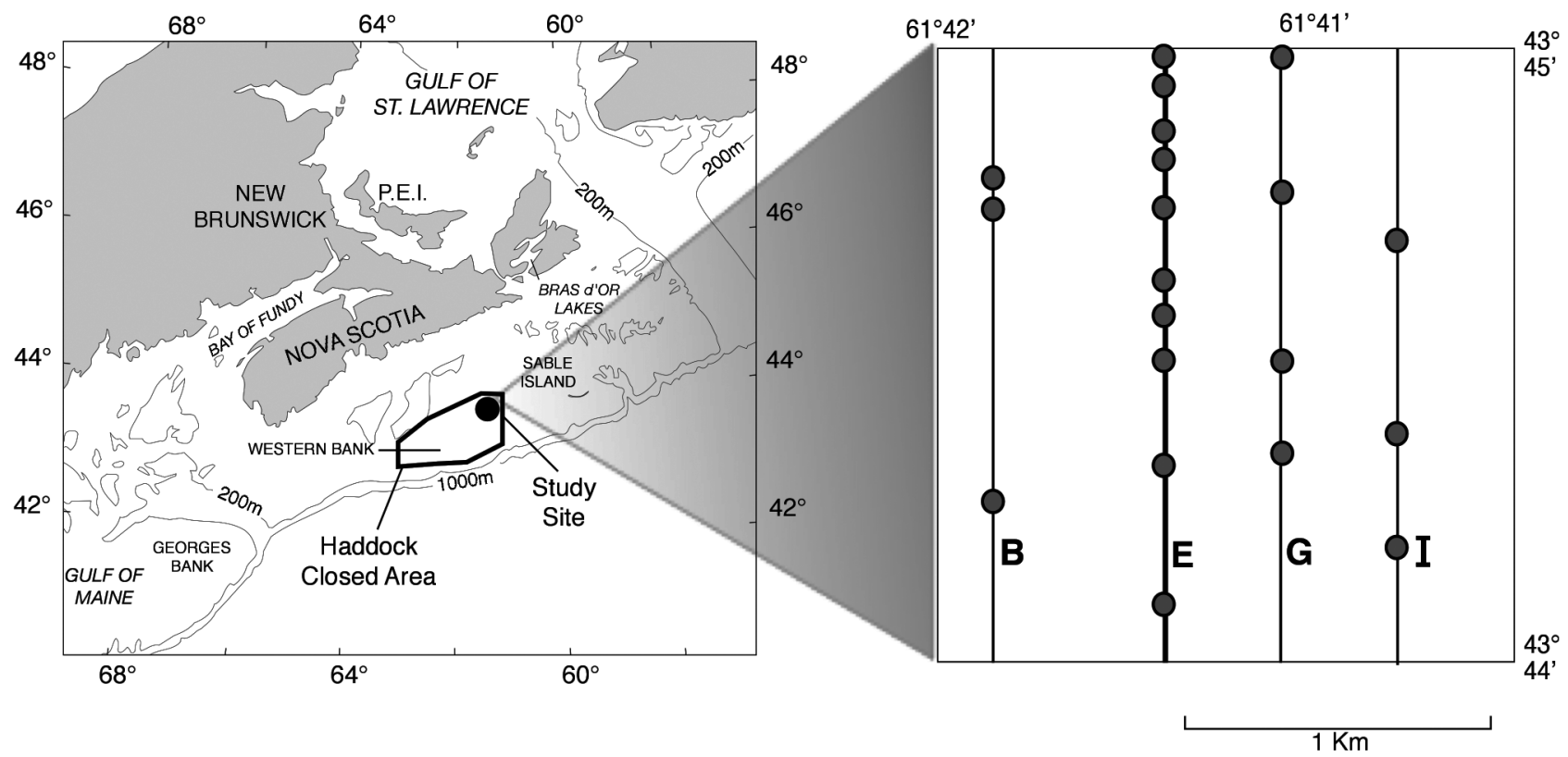

Fig. 1. Location of experimental site on Western Bank, with experimental layout (inset). Lines B, G and I were the control lines, while Line $\mathrm{E}$ was the impact line; circles indicate stations selected for Videograb sampling

effort there has been limited and the locations dredged are precisely known. This history of closure offers a rare opportunity to study the effects of trawling on a commercially important seabed, known for its high productivity of demersal fish, that has seen no mobilegear impacts for a decade.

\section{MATERIALS AND METHODS}

Experimental site. Preliminary surveys of the seabed on the eastern Scotian Shelf, conducted by Canada's Department of Fisheries and Oceans in 1996 (Gordon et al. 1998), identified a $2 \mathrm{~km} \times 2 \mathrm{~km}$ experimental site within the Haddock Box, at $43^{\circ} 45^{\prime} \mathrm{N}, 61^{\circ} 41^{\prime} \mathrm{W}$, as being suitable for a trawling impact experiment. It has a relatively homogeneous substrate and benthos. Sidescan sonar surveys showed no evidence of recent disturbance by mobile-gear bottom fishing (Gordon et al. 1998), while scallop fishery data showed that the site had not been dredged for at least $10 \mathrm{yr}$ (G. Robert, Bedford Institute of Oceanography, pers. comm.).

The site is approximately $70 \mathrm{~m}$ deep and within the photic zone, as confirmed by the presence of coralline algae (Fig. 2). Surficial sediments on Western Bank are derived from post-glacial re-working of glacial deposits and are mostly well-sorted gravel facies of the 'Sable Island Sand and Gravel' map unit (King 1970), largely composed of granitic, volcanic and metamorphic rocks. Within the experimental site itself, these form a mostly homogenous pebble to cobble bottom (clast diameters 4 to $256 \mathrm{~mm}$ : Fig. 2), although sand ( 0.0625 to $2 \mathrm{~mm}$ ), granules ( 2 to $4 \mathrm{~mm}$ ) and boulders $(>256 \mathrm{~mm}$ ) were sometimes observed (sediment classes follow Wentworth 1922).

Experimental design. An asymmetrical before-aftercontrol-impact (BACI) design (Underwood 1992, 1994, Smith 2002), comparing temporal changes on a single impacted line with those on multiple control lines, was selected. This design permitted separation of the effects of the impact from those of natural temporal and spatial variability. The use of additional control lines, rather than replicated impacted lines, reduced statistical power, but allowed more intensive trawling on the impacted line, within the limiting cost of the experiment.

Within the site, 11 equidistant, $2 \mathrm{~km}$ long lines were drawn (A through $\mathrm{K}$ ), running north to south (inset of Fig. 1). Four of them (B, E, G and I) were randomly selected for sampling, Line $\mathrm{E}$ being randomly drawn from among the 4 as that to be trawled. Then 10 sampling stations along the impact line $(\mathrm{E})$ and a further 10 stations across the multiple control lines (B, G, I) were randomly selected (inset of Fig. 1). These same 20 stations (within navigational capabilities) were sampled during each sampling period in order to reduce the contribution of spatial variability to the error term. No exact location was ever resampled, as verified by Videograb imagery. The random selection of the control and impact lines, the use of multiple control lines and the relative homogeneity of the benthos at the experimental site deflect many of the common criticisms of BACI designs (cf. Underwood 1992, Smith 2002). 


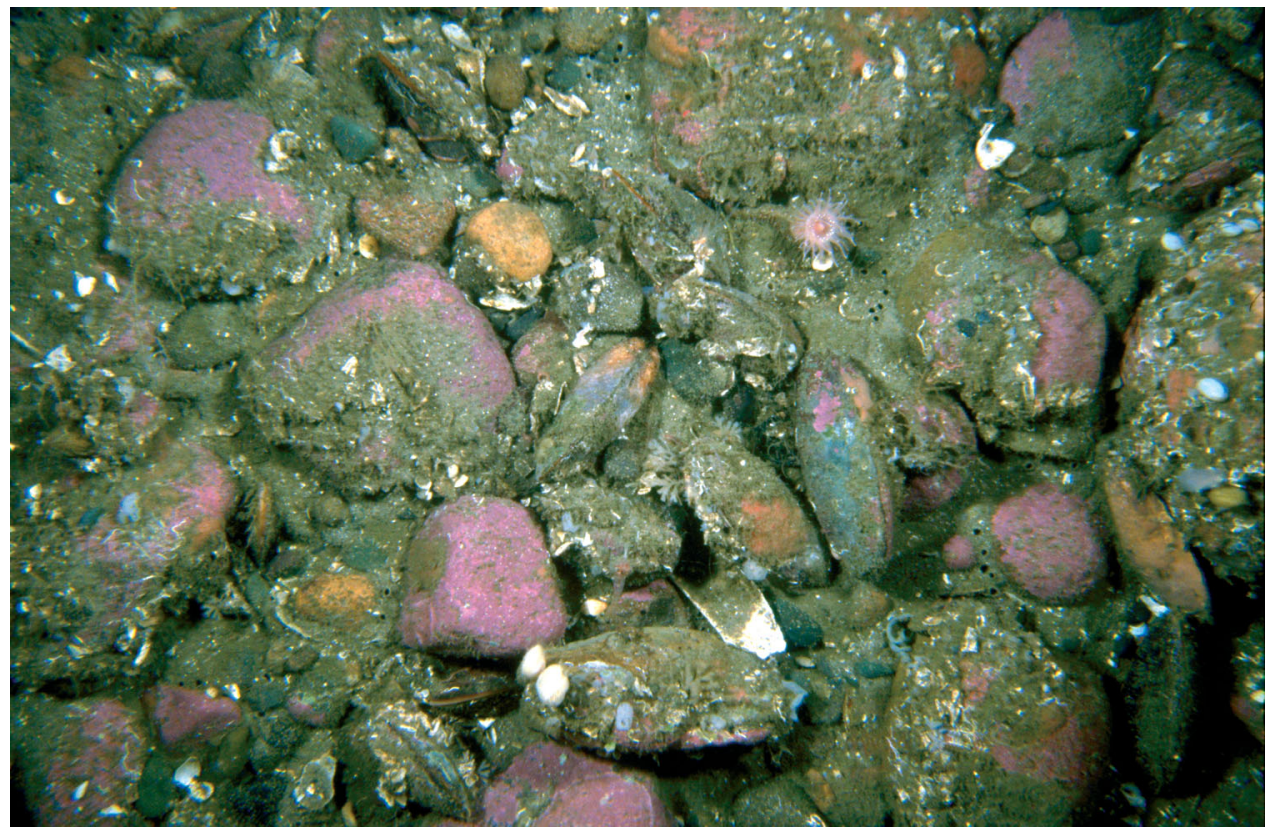

Fig. 2. Representative image of the seafloor on Western Bank taken from the impact line (E) in 1997 prior to trawling. Area depicted approximately $0.5 \mathrm{~m}^{2}$. The bryozoan Dendrobeania, with its broad, truncated branches (centre) is one of the more readily identifiable colonal species

Line E was trawled on 3 occasions from 1997 to 1999 (Table 1). In the first year, the experiment was conducted in late September, while in the latter 2 yr trawling was in late May and early June. Benthic sampling was to be done in 2 'periods', before and after trawling each year, providing a total of 120 samples over the experiment. However, logistical problems prevented this strategy from being fully implemented, particularly on the control lines before trawling in 1997 and 1998, and only 100 samples were actually collected (Table 1). This incomplete sampling put constraints on the statistical analyses that are discussed below.

Field and laboratory operations. Experimental otter trawling: Fishing was performed using an Engel 145 otter trawl equipped with rockhopper gear - the same trawl used in the earlier Grand Banks otter trawling experiment (Schwinghamer et al. 1998). The door spread was $60 \pm 5 \mathrm{~m}$, while the wing spread was $20 \pm 2 \mathrm{~m}$. Net mesh size in the wings and belly was 180 and $130 \mathrm{~mm}$, respectively, while the last $9 \mathrm{~m}$ of the $18.5 \mathrm{~m}$ long codend was fitted with a $30 \mathrm{~mm}$ square mesh liner to capture organisms which may be damaged but not retained by commercial nets. Trawling was performed by the CCGS Needler' $(1997,1999)$ and the CCGS
Table 1. Summary of sampling by Videograb at the study site (N: number of samples taken). See Fig. 1 for 'line' abbreviations

\begin{tabular}{|llccc|}
\hline Date & Period & Line & Treatment & N \\
\hline 28-29 Sep 1997 & Before & B & Control & 0 \\
& & E & Impact & 10 \\
& & G & Control & 0 \\
30 Sep-1 Oct & Trawling & I & Control & 0 \\
1-2 Oct & After & B & Control & 2 \\
& & E & Impact & 10 \\
6 Oct & & G & Control & 3 \\
23-24 May 1998 & Before & I & Control & 2 \\
& & B & Control & 0 \\
& & E & Impact & 9 \\
24 May & G & Control & 2 \\
24-25 May & Trawling & I & Control & 2 \\
& After & B & Control & 3 \\
& & E & Impact & 10 \\
13-14 May 1999 & & G & Control & 4 \\
& Before & I & Control & 3 \\
& & B & Control & 3 \\
& & E & Impact & 10 \\
2-3 Jun & & G & Control & 4 \\
4-5 Jun & Trawling & I & Control & 3 \\
& After & B & Control & 3 \\
& & E & Impact & 10 \\
& & G & Control & 4 \\
& & I & Control & 3 \\
\hline
\end{tabular}


$500 \mathrm{~m}$ beyond one end of Line $\mathrm{E}$ and continued until the gear was at least $500 \mathrm{~m}$ beyond the other end of the line, for an average tow duration of $32 \mathrm{~min}$. The trawlers were directed to tow back and forth between the same 2 waypoints to keep the trawl tracks as close together as possible. The locations of the tracks were recorded using a combination of dGPS (Differential Global Positioning System) and an ultra-short baseline acoustic tracking system (available only in 1997 and 1998). This high-precision navigation equipment showed that the trawl net strayed up to tens of metres from Line $\mathrm{E}$, considerably reducing the intensity of the experimental impact on the sampling stations (authors' unpubl. data).

Sampling of colonial epifauna: With the exceptions noted earlier, the benthos on each line was sampled (1 grab sample per station per sampling period) up to $20 \mathrm{~d}$ before and again 1 to $5 \mathrm{~d}$ after trawling (Table 1 ), using the CCGS 'Parizeau' (1997) and the CCGS 'Hudson' (1998, 1999). The range in time between sampling periods was mostly due to poor weather conditions that prevented gear deployment. A hydraulically controlled Videograb (Rowell et al. 1997, Gordon et al. 2000) was used to collect sediment and benthos from a $0.5 \mathrm{~m}^{2}$ area to a depth of 10 to $25 \mathrm{~cm}$, while simultaneously obtaining a high-resolution video of the seabed. Once landed at the sampling site by the operator, the Videograb was decoupled from the motion of the ship and the bucket was driven into the seabed hydraulically. If it did not close properly (which happened frequently because of the coarse nature of the sediment) or if there were other reasons to question sample quality, the bucket was reopened and the Videograb was moved to a new location nearby. The location of each sample was estimated using the position of the end of the boom when the Videograb hit bottom, which we have found to be a reasonable proxy. We attempted to sample as closely as possible to the nominal stations. Most samples were taken within $25 \mathrm{~m}$ of the intended point but, due to sea-state or problems getting a good sample, some were taken up to $50 \mathrm{~m}$ away.

On deck, the contents of the Videograb were dumped into a sorting tray and washed with seawater over a $1 \mathrm{~mm}$ mesh sieve; all retained material was preserved in $10 \%$ buffered formalin. Later, in the laboratory, the samples were brought into suspension, screened over a $1 \mathrm{~mm}$ mesh screen and sorted under a dissecting microscope.

Colonial epifauna were considered to be any animal comprised of physically integrated units that could potentially function independently. All sponges observed in this study were therefore considered colonial, as were most hydroids, soft corals, bryozoans and tunicates. Colonial epifauna were sorted from other organisms in the laboratory under a dissecting microscope and preserved in $70 \%$ ethanol. All specimens collected were identified to the lowest taxon possible and retained for subsequent referral for consistency of identification. Consistent taxonomic expertise used throughout the species identification process ensured that analyses would not be affected by changes in taxonomic reliability. The wet weights of each colonial taxon (after fixation and preservation) were measured to the nearest $0.1 \mathrm{mg}$. Abundance was not estimated, because it was not known whether colony fragments were derived from 1 or more colonies. Subsequent analyses therefore used either biomass or presence/ absence data. References herein to 'frequency' should be understood as the frequency of presence across samples.

Of the total 53 colonial taxa recorded, 34 were identified to species and another 12 to genus. Of those 12, only 6 hydroid genera (Halecium spp., Lafoea spp., Obelia spp., Sertularia spp., Symplectoscyphus spp. and Thuiaria spp.) likely duplicated taxa given specific identification. Those were amalgamated at the genus level for analysis (Table 2). Seven taxa were very broad designations, but, except for 3 hydroid groups, those represented taxa not otherwise recorded. The 3 exceptions, the thecate, athecate and campanulariid hydroids, are likely not independent of other identified taxa. However, 2 of them were recorded in $<3 \%$ of the grab samples, while the athecate hydroids were represented in only $13 \%$. All 3 groups were included in the analyses. In total, 33 taxa were analysed, 22 of which were hydroids (Table 2).

Data treatment and statistical analyses. Our analyses were selected to meet 2 objectives: (1) to describe natural spatial and temporal variability in colonial epifaunal assemblages over the study period and (2) to assess the impact of otter trawling on the colonial epifauna, relative to natural variability, over both the short and longer term. We also used our data to describe the colonial epifauna prior to experimental disturbance as an example of a hard-bottom, offshore assemblage undisturbed by mobile-gear fishing for at least a decade.

Our original intention was to analyse the single year and cumulative impacts of annually repeated trawling events on the number of colonial taxa and their combined biomass using an asymmetrical BACI analysis of variance (ANOVA) (Smith 2002) across the 3 yr. However, the experimental design was not fully achieved, and the number of before versus after samples was unbalanced (Table 1). Consequently, our statistical approach had to be adapted in order to meet the assumptions of the analyses.

Prior to analysis, the continuous variables were assessed for normality. The number of taxa per grab was normally distributed without transformation, as 
Table 2. Colonial epifaunal taxa. (a) All taxa collected over the duration of the study and (b) as grouped for analyses. Freq: frequency in 100 grab samples taken from 1997 to 1999

\begin{tabular}{|c|c|c|c|c|}
\hline $\begin{array}{l}\text { (a) All taxa } \\
\text { Taxon }\end{array}$ & $\begin{array}{l}\text { Taxonomic } \\
\text { group }\end{array}$ & Freq. & $\begin{array}{l}\text { (b) Taxa grouped for analyses } \\
\text { Taxon }\end{array}$ & Freq. \\
\hline Dendrobeania spp. & Bryozoan & 0.79 & Dendrobeania spp. & 0.79 \\
\hline Scypha ciliata & Sponge & 0.79 & Scypha ciliata & 0.79 \\
\hline Sertularella polyzonias & Hydroid & 0.44 & Symplectoscyphus spp. & 0.72 \\
\hline Ascophoran species & Bryozoan & 0.41 & Lafoea spp. & 0.52 \\
\hline Symplectoscyphus bathyalis & Hydroid & 0.38 & Sertularella polyzonias & 0.44 \\
\hline Porifera spp. on Terebratulina & Sponge & 0.32 & Ascophoran species & 0.41 \\
\hline Halecium muricatum & Hydroid & 0.30 & Sertularia spp. & 0.41 \\
\hline Lafoea dumosa & Hydroid & 0.30 & Halecium spp. & 0.36 \\
\hline Symplectoscyphus tricuspidatus & Hydroid & 0.25 & Porifera spp. on Terebratulina & 0.32 \\
\hline Rhizocaulus verticillatus & Hydroid & 0.25 & Rhizocaulus verticillatus & 0.25 \\
\hline Clavularia sp. & Soft coral & 0.18 & Thuiaria spp. & 0.19 \\
\hline Sertularia mirabilis & Hydroid & 0.15 & Clavularia sp. & 0.18 \\
\hline Laomedea neglecta & Hydroid & 0.13 & Laomedea neglecta & 0.13 \\
\hline Athecate hydroid species & Hydroid & 0.13 & Athecate hydroid species & 0.13 \\
\hline Scrupocellaria scabra & Bryozoan & 0.13 & Scrupocellaria scabra & 0.13 \\
\hline Lafoea spp. & Hydroid & 0.12 & Eudendrium sp. 1 & 0.12 \\
\hline Eudendrium sp. 1 & Hydroid & 0.12 & Ascidian species & 0.12 \\
\hline Porifera spp. & Sponge & 0.12 & Porifera spp. & 0.12 \\
\hline Ascidian species & Tunicate & 0.12 & Grammaria abietina & 0.12 \\
\hline Grammaria abietina & Hydroid & 0.12 & Tricellaria gracilis & 0.07 \\
\hline Sertularia schmidti & Hydroid & 0.11 & Gonothyraea loveni & 0.06 \\
\hline Sertularia spp. & Hydroid & 0.10 & Hydrallmania falcata & 0.05 \\
\hline Lafoea fruticosa & Hydroid & 0.10 & Bugula harmsworthi & 0.03 \\
\hline Symplectoscyphus spp. & Hydroid & 0.09 & Calycella syringa & 0.03 \\
\hline Sertularia tenera & Hydroid & 0.08 & Campanulariid hydroid species & 0.03 \\
\hline Lafoea gracillima & Hydroid & 0.08 & Eudendrium ramosum & 0.03 \\
\hline Thuiaria laxa & Hydroid & 0.08 & Ectopleura sp. & 0.02 \\
\hline Tricellaria gracilis & Bryozoan & 0.07 & Obelia spp. & 0.02 \\
\hline Gonothyraea loveni & Hydroid & 0.06 & Polymastia sp. & 0.02 \\
\hline Thuiaria articulata & Hydroid & 0.06 & Thecate hydroid species & 0.02 \\
\hline Hydrallmania falcata & Hydroid & 0.05 & Cuspidella procumbens & 0.01 \\
\hline Bugula harmsworthi & Bryozoan & 0.03 & Eudendrium sp. 2 & 0.01 \\
\hline Campanulariid hydroid species & Hydroid & 0.03 & Keratosum maximum & 0.01 \\
\hline Eudendrium ramosum & Hydroid & 0.03 & & \\
\hline Halecium sessile & Hydroid & 0.03 & & \\
\hline Thuiaria alternitheca & Hydroid & 0.03 & & \\
\hline Calycella syringa & Hydroid & 0.03 & & \\
\hline Ectopleura sp. & Hydroid & 0.02 & & \\
\hline Polymastia sp. & Sponge & 0.02 & & \\
\hline Thuiaria spp. & Hydroid & 0.02 & & \\
\hline Thecate hydroid species & Hydroid & 0.02 & & \\
\hline Cuspidella procumbens & Hydroid & 0.01 & & \\
\hline Eudendrium sp. 2 & Hydroid & 0.01 & & \\
\hline Halecium articulosum & Hydroid & 0.01 & & \\
\hline Halecium labrosum & Hydroid & 0.01 & & \\
\hline Halecium minutum & Hydroid & 0.01 & & \\
\hline Halecium tenellum & Hydroid & 0.01 & & \\
\hline Halecium spp. & Hydroid & 0.01 & & \\
\hline Keratosum maximum & Hydroid & 0.01 & & \\
\hline Obelia geniculata & Hydroid & 0.01 & & \\
\hline Obelia spp. & Hydroid & 0.01 & & \\
\hline Sertularia similis & Hydroid & 0.01 & & \\
\hline Thuiaria lonchitis & Hydroid & 0.01 & & \\
\hline
\end{tabular}

determined by a 1-sample Kolmogorov-Smirnov (K-S) test. Biomass required logarithmic transformation $\left(\log _{10}[\right.$ biomass+1]) to produce normally distributed data, as determined by the same test, and was used in the transformed state throughout. Homogeneity of variance was determined for each comparison between sub-groups of the data, using Levene's test.
Where the variances were unequal, a Welch 1-way ANOVA (equivalent to an adjusted Student's $t$ when there are 2 groups) was used for subsequent analyses, in place of conventional ANOVA or $t$-tests. Post hoc multiple comparisons were made using the TukeyKramer HSD (honestly significant difference) test to interpret the ANOVAs. 
All tests of null hypotheses were evaluated against a standard of $\alpha=0.05$. Given the large number of tests performed, there was a risk of multiple Type I errors and our reported results should be interpreted accordingly. For each ANOVA, adjusted power analyses (SAS Institute 2002) were performed. Statistical powers (reported below) were often low, raising a likelihood of Type II errors even with $\alpha=0.05$.

Analyses were performed using JMP Version 5 (SAS Institute 2002) and Primer Version 5.2.2 (Clarke \& Gorley 2001).

Natural variability in colonial epifauna: The natural spatial and temporal variability of the colonial epifauna was analysed in 3 stages to compensate for the sampling deficiencies. First, independent-sample $t$-tests were calculated between the numbers of taxa and the biomass in control samples (Lines B, G, I) collected after trawling in 1997 and those in the Line $\mathrm{E}$ samples collected before trawling the same year. The non-significance of this test for both variables $(p=0.30$ and $\mathrm{p}=0.21$, respectively), along with the lack of obvious mechanisms for an impact of the trawling on the control lines, justified using these post-trawling samples as indicators of pre-disturbance values.

Second, the numbers of taxa and the biomass in control samples from before and after trawling in 1998 and again in 1999 were compared using $t$-tests. The periods did not differ significantly in either 1998 (number of taxa, $\mathrm{p}=0.85$; biomass, $\mathrm{p}=0.83)$ or $1999(\mathrm{p}=0.85$, $\mathrm{p}=0.48$, respectively). Consequently, the data from control samples collected before and after trawling were combined within years. Using these pooled data, a 1-way ANOVA was used to compare the 2 variables (on the control lines only), between years 1997 and 1999. The same logic and analyses, within and between years, were applied to the transformed biomass of sponges, tunicates, soft corals, bryozoans and hydroids individually.

Finally, natural changes in colonial epifaunal assemblage composition were examined using analysis of similarity (ANOSIM) calculated from a BrayCurtis similarity matrix based on presence/absence data from the control lines. The same contrasts within and between years as were applied to the univariate data were made. Similarity of percentage (SIMPER) analyses were performed when the ANOSIM global R value was significant, in order to identify taxa that contributed most to the dissimilarity between, and similarity within, groups. The assemblages were also visually assessed using non-metric multidimensional scaling (nMDS) ordinations constructed from the Bray-Curtis matrix. A goodness-of-fit test of the regression was measured by a stress calculation, with iterations proceeding until there was no further reduction in stress.
Immediate effects of trawling: Incomplete achievement of the experimental design necessitated a different statistical approach to examine the immediate effects of trawling in each year. For 1997, the Line E samples from the 2 periods were compared using independent $t$-tests in a simple before-after design (Smith 2002). Immediate effects in 1998 and 1999 were examined using separate 2-way ANOVAs that tested the interaction between period (before, after) and location (Lines B, E, G, I). In 1998, samples from Line B were excluded to avoid an empty cell. For all $3 \mathrm{yr}$, these analyses were performed on the total number of colonial taxa, the total biomass of colonial epifauna and the biomass of each of colonial sponges, soft corals, hydroids, bryozoans and tunicates.

Immediate impacts of trawling on the colonial epifaunal assemblage composition on Line E were evaluated separately for each year using ANOSIM on a Bray-Curtis similarity matrix. Samples were grouped by period (before, after) for the analyses.

Effects of repeated trawling: The effects of repeated trawling on the number of taxa and the transformed biomass (both total and of each component group) were examined using an ANOVA design that tested the significance of period, year (1997 to 1999) and their interaction, using only the samples from Line E. If the interaction term was nonsignificant, it was removed and the analysis was rerun testing only the factors.

Effects of repeated trawling events on colonial epifaunal assemblage composition were similarly examined using a 2-way ANOSIM to test the effect of period and year (1997 to 1999) on samples from Line E. Significant results were analysed with SIMPER.

The assemblages were also compared at the conclusion of the experiment by contrasting 1999 data from the control lines with those from the impact line, after the third trawling event. This was done with ANOVA of the total number of taxa and total biomass, as well as the biomass of each component group, and with ANOSIM on the assemblage composition.

\section{RESULTS}

Colonial epifauna represented only $0.25 \%$ of the total benthic biomass over the entire study, with individual samples showing 0 to $5.6 \%$. Average colonial biomass was $2.4 \mathrm{~g} \mathrm{~m}^{-2}$ (0 to $32.6 \mathrm{~g} \mathrm{~m}^{-2}$ ). The colonial epifaunal assemblage was relatively rich: 53 taxa were identified, 42 of which were hydroids, 5 bryozoans, 4 sponges, 1 soft coral and 1 tunicate (Table 2).

The species accumulation curve across all taxa (not shown) was not saturated, indicating that the species list for the area was not complete, though the terminal 
rate of increase in the number of taxa was low. When such a curve was constructed with only the 33 taxa used in the analyses, the line approached an asymptote, allowing for meaningful comparisons between subsets of the data.

The most frequently encountered hydroids were Sertularella polyzonias, Symplectoscyphus bathyalis, Symplectoscyphus tricuspidatus, Halecium muricatum, Lafoea dumosa and Rhizocaulus verticillatus. Most of the sponges encountered were either Scypha ciliata (syn. Sycon ciliatum) or 1 of 2 unidentified species living epizoically on the brachiopod Terebratulina septentrionalis. The soft corals were all the stoloniferous Clavularia sp. The bryozoans were mostly ascophorans or Dendrobeania spp., while the sole tunicate species was an encrusting form. The 3 most common colonial taxa at the study site, the vase sponge Scypha ciliata, the hydroids Symplectoscyphus spp. and the bryozoans Dendrobeania spp., are illustrated in Fig. 3.

\section{Natural changes in colonial epifaunal assemblages}

On the control lines, the mean number of taxa and the biomass of colonial epifauna per grab sample increased significantly through the study period (Table 3, Fig. 4), the former more than doubling from 3.4 in 1997 to 8.9 in 1999. Hydroid biomass also increased, 7 -fold, through the study period. Variation between years accounted for $26 \%$ of the total variation in the number of taxa, $22 \%$ of that in total colonial epifaunal biomass and $57 \%$ of that in hydroid biomass. The biomass of the sponge, soft coral, bryozoan and tunicate epifaunal components did not change significantly $(\mathrm{p}=0.82, \mathrm{p}=0.14, \mathrm{p}=0.53, \mathrm{p}=0.55$, respectively), although the powers of those tests were low $(<0.15)$. Interannual variation will be confounded by seasonality, given that 2 yr were sampled in late May, while the 1997 sampling occurred in late September.
Table 3. Results of ANOVA of the number of taxa and biomass per grab (total and hydroid) from the control lines (B, G, I) across years (1997 to 1999)

\begin{tabular}{|lccccc|}
\hline & Year & $\begin{array}{c}\text { Mean } \\
\text { per grab }\end{array}$ & $F$ & $p$ \\
\hline Number of taxa & 1997 & 3.4 & 8.02 & 0.001 \\
& 1998 & 6.8 & & \\
$\log _{10}$ (biomass + 1) & 1999 & 8.9 & & \\
& 1997 & 2.04 & 6.47 & 0.004 \\
& 1998 & 2.35 & & \\
$\log _{10}$ (hydroid biomass + 1) & 1999 & 3.01 & & \\
& 1997 & 0.36 & 27.49 & 0.000 \\
& 1999 & 1.72 & & \\
& & 2.55 & & \\
\hline
\end{tabular}

However, both of those periods are within the growing season for these taxa and the expectation would be that biomass and the number of species would be greater in the samples taken in September, whereas the reverse was the case (Fig. 4).

Colonial epifaunal assemblages differed significantly between years (ANOSIM R $=0.313, \mathrm{p}=0.001$ ), with significant differences between all pairwise comparisons. SIMPER analyses identified 1997 and 1998 as the 2 yr with the highest average dissimilarity (69.6\%). Twenty-two taxa contributed to this dissimilarity (Table 4), with the hydroids Symplectoscyphus spp. and the bryozoans Dendrobeania spp. together accounting for $19 \%$ of it. Five hydroid taxa were absent in 1997, but occurred with moderate frequency (21 to $36 \%$ ) in 1998 (Table 4).

Average assemblage dissimilarity between 1998 and 1999 was $53.1 \%$, with an increase in the frequency of the hydroids Lafoea spp. from 36 to $80 \%$ and that of Halecium spp. from 36 to $75 \%$ accounting for $15 \%$ of the dissimilarity between years. Dissimilarity in assemblage composition between 1997 and 1999 was similar to that between 1997 and 1998 (dissimilarity 68.8\%).
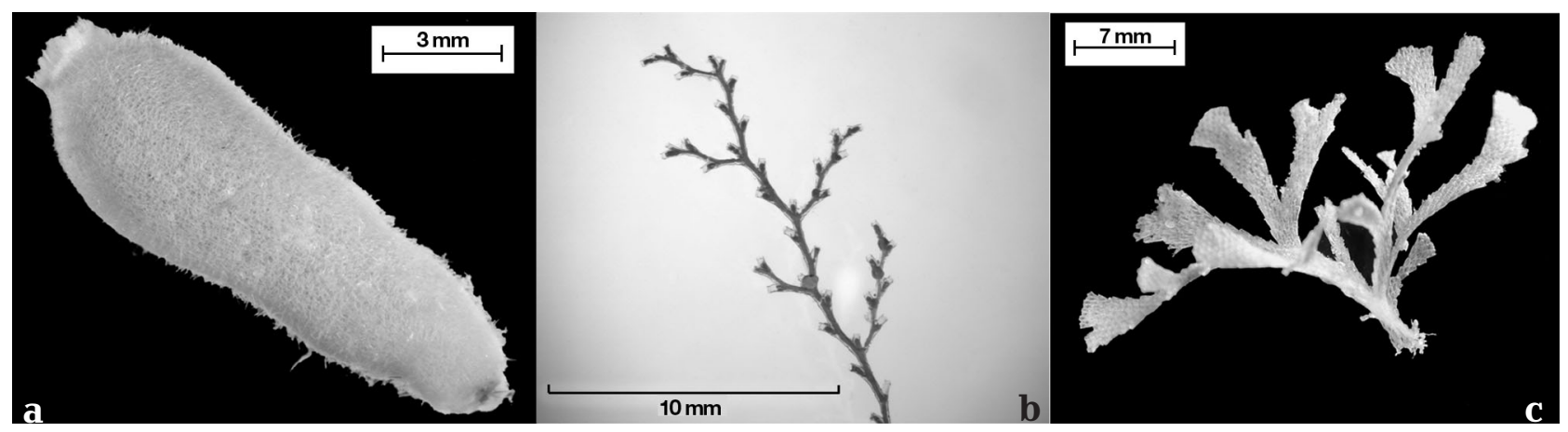

Fig. 3. The 3 most common taxa at the study site: (a) the vase sponge Scypha ciliata, (b) the hydroid Symplectoscyphus bathyalis and (c) the bryozoan Dendrobeania sp. 

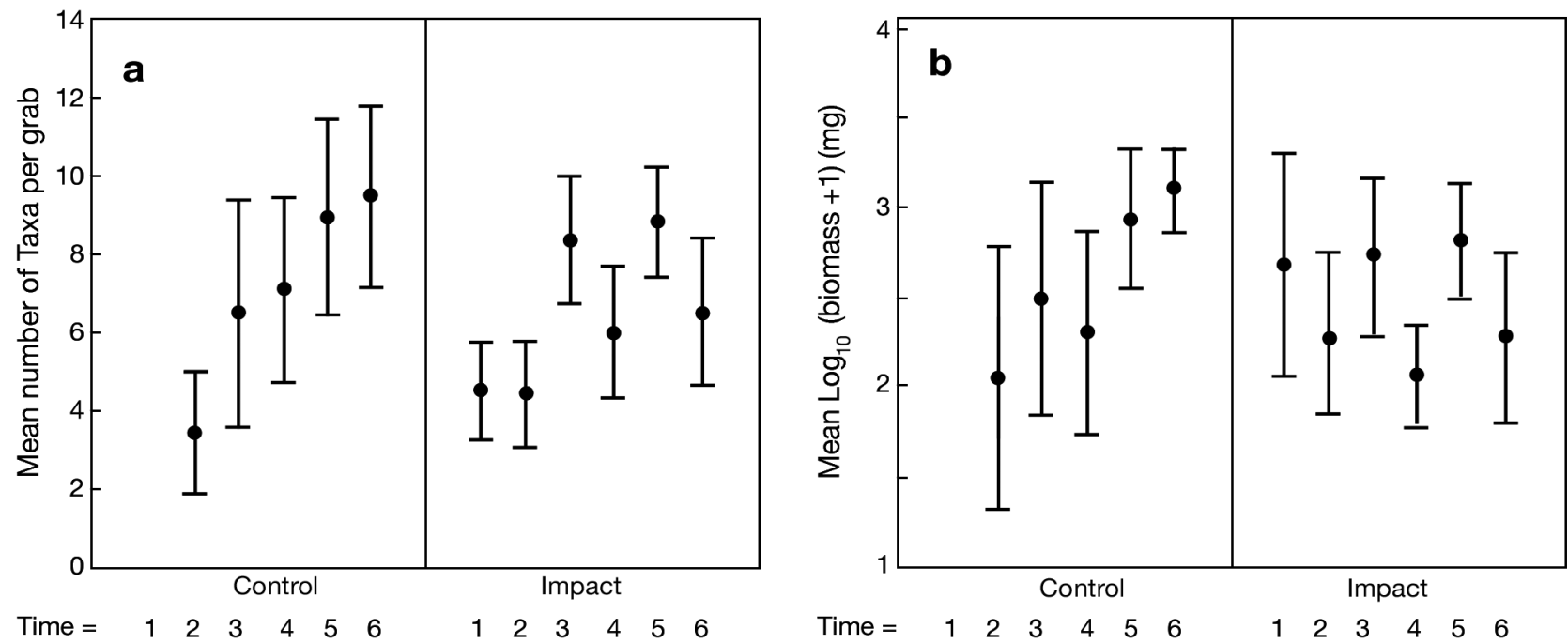

Fig. 4. Differences across treatments and temporal changes in (a) the number of colonial epifaunal taxa per grab sample and (b) their total biomass. Means $( \pm \mathrm{SE})$ are plotted. See Table 1 for sample sizes. Samples are ordered chronologically within each group from left to right: Time 1 = pre-trawl (1997), 2 = post-trawl (1997), 3 = pre-trawl (1998), $4=$ post-trawl (1998), $5=$ pre-trawl (1999), 6 = post-trawl (1999). No pre-trawl samples were obtained from the control lines in 1997

Increases in the frequency of Symplectoscyphyus spp. from 14 to $100 \%$, of Lafoea spp. from 0 to $80 \%$ and of Halecium spp. from 14 to $75 \%$ contributed $30 \%$ of the dissimilarity between those years. All taxa identified in 1997 were present in 1998 and 1999, while 10 new taxa appeared in 1998 and all but 2 of these were also taken in 1999 (Table 4).
There was high variability between samples within years, with an average similarity of only $42.5 \%$. Samples became more similar to one another over time, with the average similarity being $27.1 \%$ in 1997 , $42.3 \%$ in 1998 and $58 \%$ in 1999.

Non-metric multidimensional scaling ordination of the presence/absence data shows broad overlap

Table 4. Taxa contributing to the dissimilarity between 1997 and 1998 in assemblages on the control lines. Average dissimilarity between the 2 yr was $69.6 \%$. Frequency of occurrence in 1999 is shown, but not included in the analysis

\begin{tabular}{|c|c|c|c|c|c|c|}
\hline \multirow{2}{*}{ Taxon } & \multirow{2}{*}{$\begin{array}{l}\text { Taxonomic } \\
\text { group }\end{array}$} & \multicolumn{3}{|c|}{ Frequency } & \multirow{2}{*}{$\begin{array}{c}\text { Contribution to } \\
\text { dissimilarity } \\
\text { 1997, } 1998(\%)\end{array}$} & \multirow{2}{*}{$\begin{array}{c}\text { Cumulative } \\
\text { dissimilarity } \\
\text { 1997, } 1998 \text { (\%) }\end{array}$} \\
\hline & & 1997 & 1998 & 1999 & & \\
\hline Symplectoscyphus spp. & Hydroid & 0.14 & 0.79 & 1.00 & 10.36 & 10.36 \\
\hline Dendrobeania spp. & Bryozoan & 0.57 & 0.86 & 0.90 & 8.89 & 19.24 \\
\hline Clavularia sp. & Soft coral & 0.43 & 0.07 & 0.40 & 8.40 & 27.65 \\
\hline Sertularella polyzonias & Hydroid & 0.29 & 0.64 & 0.40 & 8.25 & 35.90 \\
\hline Scypha ciliata & Sponge & 0.71 & 0.79 & 0.85 & 7.55 & 43.45 \\
\hline Porifera spp. on Terebratulina & Sponge & 0.29 & 0.36 & 0.45 & 6.59 & 50.03 \\
\hline Sertularia spp. & Hydroid & 0.14 & 0.43 & 0.55 & 6.00 & 56.04 \\
\hline Ascophoran species & Bryozoan & 0.14 & 0.36 & 0.65 & 5.22 & 61.26 \\
\hline Ascidian species & Tunicate & 0.29 & 0.14 & 0.20 & 5.22 & 66.48 \\
\hline Halecium spp. & Hydroid & 0.14 & 0.36 & 0.75 & 5.11 & 71.59 \\
\hline Athecate hydroid species & Hydroid & 0.00 & 0.29 & 0.05 & 5.11 & 76.70 \\
\hline Lafoea spp. & Hydroid & 0.00 & 0.36 & 0.80 & 4.19 & 80.89 \\
\hline Rhizocaulus verticillatus & Hydroid & 0.00 & 0.29 & 0.35 & 3.78 & 84.67 \\
\hline Eudendrium sp. 1 & Hydroid & 0.00 & 0.29 & 0.10 & 3.61 & 88.28 \\
\hline Tricellaria gracilis & Bryozoan & 0.14 & 0.14 & 0.10 & 2.85 & 91.13 \\
\hline Gonothyraea loveni & Hydroid & 0.00 & 0.21 & 0.00 & 2.52 & 93.65 \\
\hline Porifera spp. & Sponge & 0.14 & 0.07 & 0.15 & 2.45 & 96.11 \\
\hline Obelia spp. & Hydroid & 0.00 & 0.07 & 0.00 & 1.02 & 97.13 \\
\hline Scrupocellaria scabra & Bryozoan & 0.00 & 0.07 & 0.05 & 0.85 & 97.97 \\
\hline Ectopleura sp. & Hydroid & 0.00 & 0.07 & 0.05 & 0.68 & 98.65 \\
\hline Thuiaria spp. & Hydroid & 0.00 & 0.07 & 0.15 & 0.68 & 99.32 \\
\hline Grammaria abietina & Hydroid & 0.00 & 0.07 & 0.25 & 0.68 & 100.00 \\
\hline
\end{tabular}



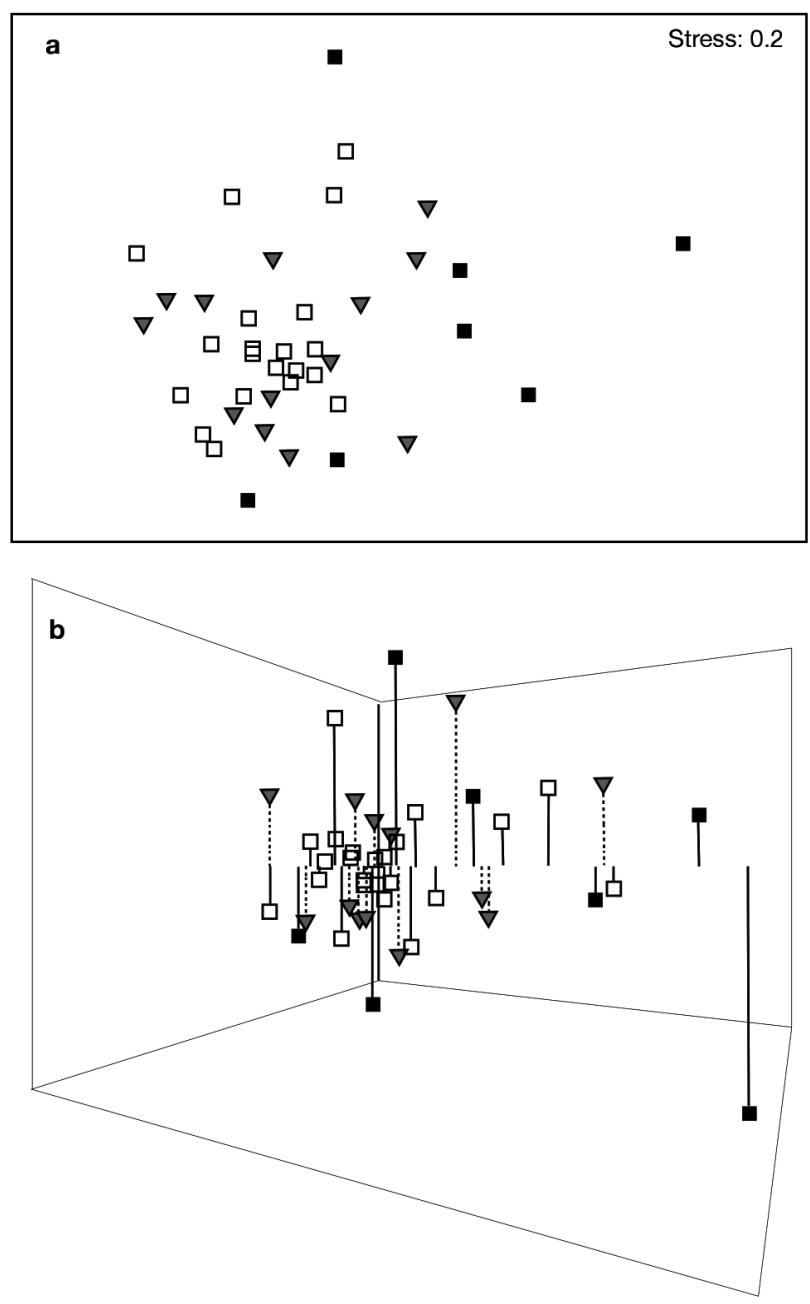

Fig. 5. Non-metric multidimensional scaling plot of assemblage composition between years on the control lines shown in (a) 2 dimensions and (b) 3 dimensions ( $\mathbf{\square}$ : 1997; $\mathbf{\nabla}$ : 1998; $\square:$ 1999)

between years (Fig. 5). The stress value was high (0.20) for the 2-dimensional representation, but adding a third dimension reduced stress to a moderate level (0.14). The third dimension revealed variability within the 1997 data, separating those data further from the 1998 and 1999 samples, which were less dispersed on the third axis.

\section{Immediate effects of trawling}

No change in the colonial epifauna was statistically detectable across individual trawling events. The number of taxa per grab did not differ statistically between periods on Line $E$ in 1997 ( $p=0.82)$. The interaction effect between period and location was non-significant in 1998 ( $p=0.64)$ and $1999(p=0.70)$.
Similarly, the biomass of colonial epifauna showed no significant difference between periods on Line $\mathrm{E}$ in 1997 ( $\mathrm{p}=0.33$ ), while the interaction term between period and location was non-significant in 1998 and in 1999 ( $\mathrm{p}=0.24$ and $\mathrm{p}=0.22$, respectively). The biomasses of sponges, soft corals, hydroids, tunicates and bryozoans individually were also not detectably affected by the trawling disturbance, when analysed separately. However, the powers of these tests were very low $(<0.16$ in all cases), and there were nonsignificant decreases in the mean number of taxa per grab sample and in their mean total biomass across each trawling event (Fig. 4). Assemblage composition on Line E did not change significantly between periods in 1997 (ANOSIM $\mathrm{R}=-0.09, \mathrm{p}=0.93), 1998(\mathrm{R}=0.06$, $\mathrm{p}=0.16)$, or $1999(\mathrm{R}=0.07, \mathrm{p}=0.15)$.

\section{Effects of repeated trawling}

ANOVA of the number of taxa, the total biomass and the biomass of each component taxon in samples from Line E, with year and period as factors, produced only non-significant interaction terms, with the exception of the analysis of soft coral biomass ( $p=0.01)$. Post hoc contrasts demonstrated that this interaction was produced by differences between years in the period effect (with soft coral absent in 1997, its biomass decreasing to zero after trawling in 1998 and increasing from zero in 1999) and is not indicative of a cumulative effect of repeated trawling. For all other variables, the interaction term was removed and the analyses were repeated, testing for main effects only. The number of colonial epifaunal taxa showed significant period and year effects (Table 5), with the number of taxa decreasing after trawling but increasing across the years, as seen on the control lines. Total biomass did not show a significant year effect, but the period effect was significant, with the mean biomass per grab decreasing after trawling. The component taxa did not show significant effects except for hydroid biomass, which decreased after trawling and increased over the study period, and the bryozoan biomass, which showed a significant year effect only, decreasing from 1998 to 1999. These results, combined with the nonsignificant interaction terms, indicate that there were immediate effects of trawling on the number of taxa and biomass that were not detectable in analyses of data from single years. However, there were no significant additional effects from the cumulative impact of repeated trawling over $3 \mathrm{yr}$.

Colonial epifaunal assemblage structure on Line E was not detectably affected by repeated trawling. Two-way ANOSIM showed no significant differences between periods (ANOSIM R $=0.01, p=0.35$ ). As on 
Table 5. Results of ANOVA of the number of taxa and biomass per grab (total, hydroid and bryozoan) from the impact line (E) across years (1997 to 1999) and before and after trawling

\begin{tabular}{|c|c|c|c|c|c|}
\hline & Factor & $\begin{array}{l}\text { Factor } \\
\text { level }\end{array}$ & $\begin{array}{c}\text { Mean } \\
\text { per grab }\end{array}$ & $F$ & $\mathrm{p}$ \\
\hline \multirow[t]{2}{*}{ Number of taxa } & Year & $\begin{array}{l}1997 \\
1998 \\
1999\end{array}$ & $\begin{array}{l}4.40 \\
7.00 \\
7.45\end{array}$ & 10.15 & 0.000 \\
\hline & Period & $\begin{array}{l}\text { Before } \\
\text { After }\end{array}$ & $\begin{array}{l}6.97 \\
5.60\end{array}$ & 5.31 & 0.025 \\
\hline \multirow[t]{2}{*}{$\log _{10}($ biomass + 1) } & Year & $\begin{array}{l}1997 \\
1998 \\
1999\end{array}$ & $\begin{array}{l}2.49 \\
2.38 \\
2.54\end{array}$ & 0.24 & 0.791 \\
\hline & Period & $\begin{array}{l}\text { Before } \\
\text { After }\end{array}$ & $\begin{array}{l}2.74 \\
2.21\end{array}$ & 8.51 & 0.005 \\
\hline \multirow[t]{2}{*}{$\log _{10}$ (hydroid biomass + 1) } & Year & $\begin{array}{l}1997 \\
1998 \\
1999\end{array}$ & $\begin{array}{l}0.98 \\
1.74 \\
2.20\end{array}$ & 16.67 & 0.000 \\
\hline & Period & $\begin{array}{l}\text { Before } \\
\text { After }\end{array}$ & $\begin{array}{l}1.82 \\
1.46\end{array}$ & 4.20 & 0.045 \\
\hline \multirow[t]{2}{*}{$\log _{10}($ bryozoan biomass +1$)$} & Year & $\begin{array}{l}1997 \\
1998 \\
1999\end{array}$ & $\begin{array}{l}1.26 \\
1.30 \\
0.77\end{array}$ & 3.16 & 0.050 \\
\hline & Period & $\begin{array}{l}\text { Before } \\
\text { After }\end{array}$ & $\begin{array}{l}1.20 \\
1.01\end{array}$ & 1.04 & 0.315 \\
\hline
\end{tabular}

the control lines, there were significant differences between years $(\mathrm{R}=0.25, \mathrm{p}=$ $0.001)$, with all years significantly different from each other $(\mathrm{p}<0.01)$ in pairwise comparisons. SIMPER analyses found the assemblages to be heterogeneous within years, with similarity between samples ranging from $44 \%$ in 1997 to $51 \%$ in 1999.

The analysis identified 1997 and 1999 as the most dissimilar years, with 28 taxa contributing to this dissimilarity (Table 6). The hydroid taxa Symplectoscyphyus spp., Lafoea spp. and Halecium spp. contributed $28 \%$ of the dissimilarity between those years, all increasing in frequency of occurrence. Symplectoscyphyus spp. contributed most to the dissimilarity between years in the control lines. A comparison of Tables 4 and 6 shows that 8 taxa are common to the top 10 of each, indicating a similarity of temporal change on Line $\mathrm{E}$, as on the control lines.

Table 6. Taxa contributing to the dissimilarity between 1997 and 1999 in assemblages on the impact line. Average dissimilarity between the 2 yr was $64.7 \%$. Frequency of occurrence in 1998 is shown, but not included in the analysis

\begin{tabular}{|c|c|c|c|c|c|c|}
\hline \multirow{2}{*}{ Taxon } & \multirow{2}{*}{$\begin{array}{l}\text { Taxonomic } \\
\text { group }\end{array}$} & \multicolumn{3}{|c|}{ Frequency } & \multirow{2}{*}{$\begin{array}{l}\text { Contribution to } \\
\text { dissimilarity } \\
\text { 1997, } 1999(\%)\end{array}$} & \multirow{2}{*}{$\begin{array}{c}\text { Cumulative } \\
\text { dissimilarity } \\
1997,1999(\%)\end{array}$} \\
\hline & & 1997 & 1998 & 1999 & & \\
\hline Symplectoscyphus spp. & Hydroid & 0.30 & 0.74 & 1.00 & 10.48 & 10.48 \\
\hline Lafoea spp. & Hydroid & 0.20 & 0.53 & 0.85 & 10.01 & 20.49 \\
\hline Halecium spp. & Hydroid & 0.00 & 0.16 & 0.60 & 7.58 & 28.07 \\
\hline Porifera spp. on Terebratulina & Sponge & 0.30 & 0.05 & 0.45 & 6.29 & 34.36 \\
\hline Sertularia spp. & Hydroid & 0.30 & 0.58 & 0.30 & 5.80 & 40.16 \\
\hline Ascophoran species & Bryozoan & 0.30 & 0.53 & 0.30 & 5.72 & 45.89 \\
\hline Sertularella polyzonias & Hydroid & 0.20 & 0.63 & 0.45 & 5.65 & 51.54 \\
\hline Rhizocaulus verticillatus & Hydroid & 0.05 & 0.21 & 0.45 & 5.64 & 57.18 \\
\hline Scypha ciliata & Sponge & 0.90 & 0.79 & 0.65 & 5.63 & 62.80 \\
\hline Dendrobeania spp. & Bryozoan & 0.75 & 0.79 & 0.75 & 5.50 & 68.30 \\
\hline Thuiaria spp. & Hydroid & 0.30 & 0.32 & 0.15 & 5.01 & 73.31 \\
\hline Scrupocellaria scabra & Bryozoan & 0.20 & 0.26 & 0.10 & 3.10 & 76.41 \\
\hline Grammaria abietina & Hydroid & 0.15 & 0.00 & 0.15 & 3.07 & 79.48 \\
\hline Porifera spp. & Sponge & 0.20 & 0.11 & 0.05 & 3.02 & 82.50 \\
\hline Laomedea neglecta & Hydroid & 0.00 & 0.00 & 0.20 & 2.54 & 85.04 \\
\hline Eudendrium sp. 1 & Hydroid & 0.00 & 0.11 & 0.20 & 2.27 & 87.31 \\
\hline Athecate hydroid species & Hydroid & 0.05 & 0.26 & 0.10 & 2.08 & 89.39 \\
\hline Clavularia sp. & Soft coral & 0.00 & 0.16 & 0.15 & 1.99 & 91.38 \\
\hline Ascidian species & Tunicate & 0.10 & 0.05 & 0.05 & 1.78 & 93.16 \\
\hline Calycella syringa & Hydroid & 0.00 & 0.00 & 0.15 & 1.60 & 94.76 \\
\hline Hydrallmania falcata & Hydroid & 0.00 & 0.05 & 0.10 & 0.99 & 95.75 \\
\hline Eudendrium ramosum & Hydroid & 0.05 & 0.11 & 0.00 & 0.71 & 96.46 \\
\hline Polymastia sp. & Sponge & 0.00 & 0.05 & 0.05 & 0.69 & 97.16 \\
\hline Campanulariid hydroid species & Hydroid & 0.00 & 0.05 & 0.05 & 0.64 & 97.79 \\
\hline Thecate hydroid species & Hydroid & 0.00 & 0.05 & 0.05 & 0.64 & 98.43 \\
\hline Eudendrium sp. 2 & Hydroid & 0.00 & 0.00 & 0.05 & 0.54 & 98.97 \\
\hline Cuspidella procumbens & Hydroid & 0.00 & 0.00 & 0.05 & 0.54 & 99.52 \\
\hline Bugula harmsworthi & Bryozoan & 0.05 & 0.05 & 0.00 & 0.48 & 100.00 \\
\hline
\end{tabular}


At the conclusion of the experiment, the total number of epifaunal taxa, the biomass of sponges, soft corals and tunicates and the composition of colonial epifaunal assemblages on the impact line, after 3 yr of repeated trawling, were not significantly different from those on the adjacent control lines $(\mathrm{p}=0.07, \mathrm{p}=$ 0.95, $\mathrm{p}=0.06, \mathrm{p}=0.18$; ANOSIM $\mathrm{R}=0.06, \mathrm{p}=0.24$, respectively). However, total biomass was significantly lower on Line $E(p=0.003)$, as was the biomass of hydroids $(p=0.01)$ and that of bryozoans $(p=0.01)$.

\section{DISCUSSION}

After 10 yr of effective closure to bottom fishing with mobile gear, the study area on Western Bank had a rich and diverse assemblage of colonial epifauna, with at least 53 identified taxa. Hydroids composed the majority of taxa observed and amongst them the most frequently occurring taxa (present at $>25 \%$ of stations) shared similar characteristics. All have a branched phalanx growth form, can grow to sizes $>50 \mathrm{~mm}$, have planula larvae when reproducing sexually and live for a number of years, characteristics consistent with species inhabiting undisturbed substrata (cf. Henry \& Kenchington 2004b).

Colonial species assemblages in the study area were highly variable in space and dynamic in time. The similarity between samples from the untrawled control lines was relatively low, reflecting spatial heterogeneity in species composition across scales of hundreds of metres. On those same lines, the mean number of taxa per grab sample, their combined biomass and the frequencies of occurrence of most taxa all increased significantly from 1997 to 1999. The number of taxa per sample more than doubled over those years, while 3 taxa that were entirely absent in 1997 were found in $>25 \%$ of the samples taken 2 yr later. For example, Lafoea spp., which were absent in 1997, appeared in $36 \%$ of grab samples the following year and in $80 \%$ in 1999. Not all species showed this increase, but none showed marked declines in observed frequency over time. Thus, not only was the assemblage highly dynamic, but it appears that the years of the study saw favourable conditions for recruitment of a range of colonial epifaunal species, particularly hydroids, at the study site.

The increase in biomass over time in control samples suggests that the colonial epifauna were not space limited in the late 1990s. Still photographs and video showing much unoccupied hard substrate also suggest that local habitats were not fully occupied, despite the prolonged period without disturbance by mobile fishing gear. The cobble seabed of the study site had not been extensively grown over by epibenthos (Fig. 2).
It is possible that recovery of the colonial epifauna, following the cessation of decades of trawling impacts previous to 1987, was still in progress and will continue for a long time to come. On similar gravel seabeds on Georges Bank, epifaunal recovery continued for at least 6 yr following closure to trawling (Hermsen et al. 2003). Alternatively, natural processes, such as predation and periodic storm disturbance, may repeatedly reset benthic assemblages on Western Bank to earlier successional stages, preventing colonial epifauna from ever fully occupying available seabed space.

A priori, trawling at this site was expected to reduce both the number of colonial taxa per grab sample and their biomass, but neither effect could be detected in analyses of data from single years. Only in the 2-way ANOVAs, using data from all $3 \mathrm{yr}$, were short-term effects of trawling on these variables detectable at $\alpha=0.05$. One analysis detected a significant decline in hydroid biomass, though not one large enough to explain the entire change in colonial epifaunal biomass. Although there was a decline in the total number of species per grab sample after trawling in each year, no significant change in assemblage composition was detected.

These few conclusions of 'significance' are, however, based on probabilities associated with single tests. Application of Hochberg's (1998) 'sharper' Bonferroni adjustment to the results reported here would suggest that only those of $\mathrm{p} \leq 0.001$ should be accepted as significant. The 4 tests that met that condition all concerned inter-annual change, with 2 each on the control lines and on Line E. None concerned any effects of trawling disturbance. The powers of many tests were low, however, even at $\alpha=0.05$, and it cannot be said that this experiment demonstrated the absence of trawling impacts on the colonial epifauna of Western Bank. What is clear is that any impacts were small, relative to the degree of natural inter-annual change. Furthermore, the colonial epifauna showed no detectable indication of any accumulated effect of repeated trawling, suggesting that recovery from each trawl-disturbance event was essentially complete within a year.

Similarly limited impacts of mobile fishing gear have been previously reported for infaunal communities (e.g. Eleftheriou \& Robertson 1992, Kenchington et al. 2001), but were not expected for hard-bottom, sessile epifauna. The contrary results of our experiment may be due, in part, to the morphological configurations and life histories of the resident taxa that render them less vulnerable to the gear. Unlike sessile epifaunal assemblages dominated by erect, rigid megabenthic sponges and corals, the colonial epifauna in the study area was dominated by flexible Dendrobeania spp. (Bryozoa), a small epizoic sponge, Scypha ciliata, and 
several hydroids (Fig. 3), which may generally be less vulnerable to immediate removal than more rigid species. Morphological rigidity has been suggested as an important factor in determining the fate of benthos exposed to bottom fishing (Bremner et al. 2003). The erect but flexible colonial taxa at our study site likely passed under the otter trawl and its rockhopper gear with only limited harm, this net being relatively inefficient at removing benthos (Prena et al. 1996, Kenchington et al. 2005). Equally, the cobbles themselves may afford protection by providing an uneven surface with crevices untouched by the gear. Some colonial species, such as the hydroid Sertularella polyzonias, can also rapidly recolonise new substrates via asexual propagation. By using terminal tendrils located at the distal ends of each hydroid plume (Cornelius 1995), this species can rapidly regenerate, a process that would swiftly obliterate any losses to trawling.

The limited detected effects may also have resulted, in part, from the moderate intensity of trawling disturbance. Had they all passed down the same track, the 12 or 14 tows each year would have represented a concentration of effort greater than has generally been applied by the commercial fisheries off Atlantic Canada (Kulka \& Pitcher 2001). However, the lateral spread of the tracks, while only a few tens of metres, was considerable relative to the width of each one, thus substantially reducing the number of passes of the gear across each sampling station. The Videograb sampling also drifted away from its intended locations to an extent comparable to the width of a trawl track. We (authors' unpubl. data) have compared the recorded trawl tracks (between the otter boards) in 1997 and 1998 with the actual collection locations of the Videograb samples to determine how many passes of the trawl gear affected each sample. Each sampling location was crossed by an average of 8.4 tracks in 1997 (range 1 to 12 times), 4.0 in 1998 (range 2 to 6) and likely a similar number in 1999, though there are no acoustic tracking data for that year (authors' unpubl. data). For the tracks of the net itself (between the wings), the corresponding figures were 3.9 in 1997 (range 0 to 8) and 1.0 in 1998 (range 0 to 3). To our knowledge, the tracks of the otter boards were never sampled by the Videograb during this experiment.

Furthermore, the relatively narrow swath of experimental trawling, relative to broadly disturbed commercial fishing effort, may have allowed rapid recovery through a degree of recolonisation from the unfished areas on either side, which might not have occurred if the whole bank had been subject to the intensity of trawling used on the one line. Other benthic populations appear to persist in the face of trawling impacts through recruitment of locally abundant species surviving in non-impacted areas (Osman \& Whitlach
1998, Pranovi et al. 1998, Frid et al. 2000). Also, the effects of the annual, pulsed experimental disturbance may have differed from those which would have resulted if the disturbance had been spread over the year, as would be more typical of commercial fisheries. However, it cannot be said which seasonal pattern would have caused the greater impact.

There have been few manipulative experiments comparable to ours into the effects of otter trawling on the benthos of gravel or other hard-bottom seabeds. Van Dolah et al. (1987) made 1 tow across a shallow (approximately $20 \mathrm{~m}$ ), previously untrawled site off Georgia, USA, which had abundant sponges, corals and other colonial organisms. The authors observed damage to individuals of various taxa, but only the density of barrel sponges was significantly reduced. Much as on Western Bank, 12 mo after the trawling, abundance had recovered and the damage to sponges and corals was no longer detectable. Bradshaw et al. (2001) reported on some experimental scallop dredging, within an otherwise closed area off the Isle of Man. They found a tendency for the benthos in the experimental area to become more like that in areas regularly dredged, but the changes were not statistically significant.

In marked contrast, Freese et al. (1999) trawled 8 sites, once each, on a gravel bottom in the eastern Gulf of Alaska, at depths of 206 to $274 \mathrm{~m}$, in an area which had seen little or no trawling for many years and which supported rich growths of mega-epibenthos, particularly large sponges. After the fishing, they examined both the trawl tracks and adjacent control transects using a submersible, observing displaced boulders, damaged sponges and seawhips, plus reduced densities of both those colonial organisms and of sea anemones. One year later, there was no sign of recovery and indeed some indication of further loss as damaged sponges died (Freese 2003). On Australia's Northwest Shelf and at a depth (50 m) more comparable to that of our experiment, Moran \& Stephenson (2000) trawled across a previously untrawled site that had an abundance of large (>200 mm) megabenthos. Four passes of their gear depleted the density of such organisms by about half. Burridge et al. (2003) found similar rates of depletion of some taxa when a prawn trawl was towed through areas of sponges, gorgonians and hard corals, at 20 to $35 \mathrm{~m}$ depth, in channels amidst the Great Barrier Reef. Since Freese et al. (1999) worked in such a different environment from the 2 Australian teams, the contrast between all of their results and those reported here seems likely due to differences in the epibenthic assemblages, rather than depth, substrate type, or water temperature. Each of their study sites supported rich growths of erect megaepibenthic colonies, which would be expected to be 
vulnerable to trawling. In contrast, the sponges found at our site on Western Bank were relatively small, soft corals were infrequent and no gorgonians or seawhips occurred.

Our experimental results from Western Bank may also be compared with observations by Collie et al. (1997, 2000) and Hermsen et al. (2003) on the benthos of gravel seabeds on Georges Bank, $<500 \mathrm{~km}$ west of our site. Collie et al. $(1997,2000)$ did not conduct manipulative experiments, but rather compared the benthos at 6 selected sites, at depths of approximately 45 and $85 \mathrm{~m}$, with contrasting inferred histories of fishing. Besides the expected differences in species composition with depth and in apparent contradiction to our results, Collie et al. (1997, 2000) reported differences in the benthos between sites deemed to be 'disturbed' by trawling and dredging and those considered 'undisturbed', with the latter having more species, higher biomass and numbers of organisms, lower evenness and perhaps higher diversity. The colonial taxa were excluded from Collie et al.'s (1997) analysis of dredge-sampled benthos, and from Hermsen et al.'s (2003) subsequent study of temporal trends at the same site, since it was thought that the gear did not sample them quantitatively. However, photographic and video records (Collie et al. 2000) showed erect colonial forms to be usually (though not invariably) more abundant at 'undisturbed' sites, while encrusting bryozoans were more common at 'disturbed' ones. Those authors concluded that the emergent colonial epifauna provide complex habitat, utilised by many species, at undisturbed sites, but that fishing gear removes this epifauna (Collie et al. 2000).

Certain of Collie et al.'s (2000) sites have probably seen continuous, intense fishing with both trawls and scallop dredges for some decades; hence, their observations may represent the cumulative effects of chronic disturbances far exceeding anything that could be exerted during an experiment, such as ours. However, their 'undisturbed' deep sites had welldeveloped growths of the tube-building polychaetes Filograna implexa and Protula tubularia, which provided habitats for other organisms, which in turn accounted for much of the increased species number and diversity. Our study site on Western Bank lacked such a developed turf-forming epifauna, despite the prolonged absence of mobile, bottom-tending fishing gear, and thus had a benthic assemblage that may have been less vulnerable to trawling, including our experimental trawling, than those seen on some parts of Georges Bank - whether because of exceptionally slow recovery following closure or because of marked natural differences in the benthos is unclear. In either case, our results indicate that Collie et al.'s $(1997,2000)$ characterisation of the effects of fishing gear may not be universally applicable to all previously trawled, gravel seabeds in the northwest Atlantic.

While a controlled, manipulative experiment, such as that on Western Bank, cannot mimic the impacts of the extensive, chronic commercial trawling and dredging studied by Collie et al. (1997, 2000) and Hermsen et al. (2003), our results do directly address the effects of the first few tows across a cobble seabed following a prolonged period without disturbance by mobile fishing gear. The benthos on that bottom type is often supposed to be particularly vulnerable to disturbance by fishing gear (e.g. National Research Council 2002). Furthermore, while some authorities have suggested near-linear responses to increasing intensities of trawling, at least as first approximations (e.g. Auster 1998, National Research Council 2002), it has recently been suggested that the most pronounced effects will be seen when an area is fished for the first time (e.g. Blyth et al. 2004, Laffoley \& Tasker 2004, Royal Commission on Environmental Pollution 2004). Yet, on Western Bank there were no prominent effects on the colonial epifauna of the first passes of the trawl.

Indeed, despite the moderate levels of trawling disturbance applied in our experiment, very few significant and no lasting effects were observed. Such impacts on the colonial epifauna as were indicated by our data were small, relative to the natural, interannual change. We suggest that the absence of more pronounced effects was in part a consequence of the relatively low frequency on the study site of the large, sessile colonies that appear most vulnerable to mobile fishing gear. We conclude that substrate type, while important in determining species composition, is not itself a good predictor of the effects of fishing gear on the benthos. Instead, the morphologies of the resident taxa, their biology and life histories are key determinants.

Acknowledgements. We thank the captains and crews of the CCGSs 'Hudson', 'Needler', 'Parizeau' and 'Teleost' for their assistance and expertise that was instrumental to this field experiment and our numerous colleagues who helped collect and process the Videograb samples. We thank D. Schneider and K. Gilkinson for their assistance with the experimental design. The Geological Survey of Canada (Atlantic) (NRCan) and D. McKeown supported this experiment by providing the necessary ORE Trackpoint II acoustic systems and interpretations. We thank G. Fader at NRCan for geological interpretations, and P. Vass for ensuring the smooth operation of the Videograb. Criticisms of this paper were provided by C. L. J. Frid, R. Scheibling, K. Gilkinson and 3 anonymous referees. Their comments greatly added to the manuscript. Funding was provided by the Strategic Research Fund of DFO, a research grant from the Natural Sciences and Engineering Research Council (NSERC) of Canada (E.L.R.K.), a post-graduate NSERC scholarship (L.-A.H.), a DFO-NSERC supplemental award (L.-A.H.) and the Fisheries Survival Fund (T.J.K.). 


\section{LITERATURE CITED}

Auster PJ (1998) A conceptual model of the impacts of fishing gear on the integrity of fish biomass. Conserv Biol 12: 1198-1203

Black KP, Parry GD (1994) Sediment transport rates and sediment disturbance due to scallop dredging in Port Phillip Bay. Mem Qld Mus 36:327-341

Black KP, Parry GD (1999) Entrainment, dispersal and settlement of scallop dredge sediment plumes: Field measurements and numerical modelling. Can J Fish Aquat Sci 56: 2271-2281

Blyth RE, Kaiser MJ, Edwards-Jones G, Hart PBJ (2004) Implications of a zoned fishery management system for marine benthic communities. J Appl Ecol 41:951-961

Bradshaw C, Veale LO, Hill AS, Brand AR (2001) The effect of scallop dredging on Irish Sea benthos: experiments using a closed area. Hydrobiologia 465:129-138

Bremner J, Frid CLJ, Rogers SI (2003) Assessing marine ecosystem health: the long-term effects of fishing on functional biodiversity in North Sea benthos. Aquat Ecosyst Health Manag 6:131-137

Burridge CY, Pitcher CR, Wassenberg TJ, Poiner IR, Hill BJ (2003) Measurement of the rate of depletion of benthic fauna by prawn (shrimp) otter trawls: an experiment in the Great Barrier Reef, Australia. Fish Res 60:237-253

Caddy JF (1973) Underwater observations on tracks of dredges and trawls and some effects of dredging on a scallop ground. J Fish Res Board Can 30:173-180

Churchill JH (1989) The effect of commercial trawling on sediment resuspension and transport over the Middle Atlantic Bight continental shelf. Cont Shelf Res 9:841-864

Clarke KR, Gorley RN (2001) PRIMER v5: user manual/ tutorial. PRIMER-E, Plymouth

Collie JS, Escanero GA, Valentine PC (1997) Effects of bottom fishing on the benthic megafauna of Georges Bank. Mar Ecol Prog Ser 155:159-172

Collie JS, Escanero GA, Valentine PC (2000) Photographic evaluation of the impacts of bottom fishing on benthic epifauna. ICES J Mar Sci 57:987-1001

Cornelius PFS (1995) North-west European thecate hydroids and their medusae. Part 2. Sertulariidae to Campanulariidae. In: Barnes RSK, Crothers JH (eds) Synopses of the British fauna (new series). Field Studies Council, Shrewsbury

Currie DR, Parry GD (1996) Effects of scallop dredging on a soft sediment community: a large-scale experimental study. Mar Ecol Prog Ser 134:131-150

Eleftheriou A, Robertson MR (1992) The effects of experimental scallop dredging on the fauna and physical environment of a shallow sandy community. Neth J Sea Res 30: $289-299$

Fosså JH, Mortensen PB, Furevik DM (2002) The deep-water coral Lophelia pertusa in Norwegian waters: distribution and fishery impacts. Hydrobiologia 471:1-12

Freese L (2003) Trawling-induced damage to sponges observed from a research submersible. Mar Fish Rev 63:7-13

Freese L, Auster PJ, Heifetz J, Wing BL (1999) Effects of trawling on seafloor habitat and associated invertebrate taxa in the Gulf of Alaska. Mar Ecol Prog Ser 182:119-126

Frid CLJ, Harwood KG, Hall SJ, Hall JA (2000) Long-term changes in the benthic communities on North Sea fishing grounds. ICES J Mar Sci 57:1303-1309

Gili JM, Hughes RG (1995) The ecology of marine benthic hydroids. Oceanogr Mar Biol Annu Rev 33:351-426

Goldson AJ, Hughes RN, Gliddon CJ (2001) Population genetic consequences of larval dispersal mode and hydrography: a case study with bryozoans. Mar Biol 138: 1037-1042

Gordon DC Jr, Schwinghamer P, Rowell TW, Prena J, Gilkinson K, Vass WP, McKeown DL (1998) Studies in eastern Canada on the impact of mobile fishing gear on benthic habitat and communities. In: Dorsey EM, Pederson J (eds) Scientific studies of fishing gear effects. Conservation Law Foundation, Boston, MA

Gordon DC Jr, Kenchington ELR, Gilkinson KD, McKeown DL, Steeves G, Chin-Yee M, Bentham K, Boudreau PR (2000) Canadian imaging and sampling technology for studying marine benthic habitat and biological communities. ICES/CM T:07

Hall-Spencer J, Allain V, Fosså JH (2002) Trawling damage to northeast Atlantic ancient coral reefs. Proc R Soc Lond B Biol Sci 269:507-511

Henry LA, Kenchington EL (2004a) Ecological and genetic evidence for impaired sexual reproduction and induced clonality in the hydroid Sertularia cupressina (Cnidaria: Hydrozoa) on commercial scallop grounds in Atlantic Canada. Mar Biol 145:1107-1118

Henry LA, Kenchington EL (2004b) Differences between epilithic and epizoic hydroid assemblages from commercial scallop grounds in the Bay of Fundy, northwest Atlantic. Mar Ecol Prog Ser 266:123-134

Hermsen JM, Collie JS, Valentine PC (2003) Mobile fishing gear reduces benthic megafaunal production on Georges Bank. Mar Ecol Prog Ser 260:97-108

Hochberg Y (1998) A sharper Bonferroni procedure for multivariate tests of significance. Biometrika 75:800-802

Innis HA (1954) The cod fisheries: the history of an international economy. University of Toronto Press

Jackson JBC (1986) Modes of dispersal of clonal benthic invertebrates: consequences for species distribution and genetic structure of local populations. Bull Mar Sci 39: 588-606

Jennings S, Kaiser MJ (1998) The effects of fishing on marine ecosystems. Adv Mar Biol 34:201-252

Kenchington ELR, Prena J, Gilkinson KD, Gordon DC Jr and 6 others (2001) Effects of experimental otter trawling on the macrofauna of a sandy bottom ecosystem on the Grand Banks of Newfoundland. Can J Fish Aquat Sci 58: 1043-1057

Kenchington ELR, Gordon DC Jr, Bourbonnais C, MacIsaac KG, Gilkinson KD, McKeown DL, Vass WP (2005) Effects of experimental otter trawling on the feeding of demersal fish on Western Bank, Nova Scotia. Am Fish Soc Symp 41:391-409

King LH (1970) Surficial geology of the Halifax-Sable Island map area. Geol Surv Can Mar Sci Pap 1:1-16

Koslow JA, Gowlett-Holmes K, Lowry JK, O'Hara T, Poore GCB, Williams A (2001) Seamount benthic macrofauna off southern Tasmania: community structure and impacts of trawling. Mar Ecol Prog Ser 213:111-125

Kulka DW, Pitcher DA (2001) Spatial and temporal patterns in trawling activity in the Canadian Atlantic and Pacific. ICES CM 2001/R:02

Laffoley D, Tasker M (2004) Marine environment. Prime Minister's Strategy Unit, Cabinet Office, London

McKenzie RA (1946) The haddock fishery of grounds fished by Canadians. Bull Fish Res Board Can 69:1-30

Moran MJ, Stephenson PC (2000) Effects of otter trawling on macrobenthos and management of demersal scalefish fisheries on the continental shelf of north-western Australia. ICES J Mar Sci 57:510-516

National Research Council (2002) Effects of trawling and dredging on seafloor habitat. Committee of Ecosystem 
Effects of Fishing, Ocean Studies Board, National Academy Press, Washington, DC

Orlov D (1997) Epizoic associations among the White Sea hydroids. Sci Mar 61:17-26

Osman RW, Whitlach RB (1998) Local control of recruitment in an epifaunal community and the consequences to colonization processes. Hydrobiologia 375/376:113-123

Pitcher CR, Poiner IR, Hill BJ, Burridge CY (2000) Implications of the effects of trawling on sessile megazoobenthos on a tropical shelf in northeastern Australia. ICES J Mar Sci 57:1359-1368

Pranovi F, Giovanardi O, Franceschini G (1998) Recolonization dynamics in areas disturbed by bottom fishing gears. Hydrobiologia 375/376:125-135

Prena J, Rowell TW, Schwinghamer P, Gilkinson K, Gordon DC Jr (1996) Grand Banks otter trawling impact experiment. 1. Site selection process, with a description of macrofaunal communities. Can Tech Rep Fish Aquat Sci 2094:1-38

Pulfrich A (1996) Attachment and settlement of post-larval mussels (Mytilus edulis L.) in the Schleswig-Holstein Wadden Sea. J Sea Res 36:239-250

Rinkevich B (1996) Do reproduction and regeneration in damaged corals compete for energy allocation? Mar Ecol Prog Ser 143:297-302

Rowell TW, Schwinghamer P, Chin-Yee M, Gilkinson KD and 11 others (1997) Grand Banks otter trawling experiment. III. Sampling equipment, experimental design, and methodology. Can Tech Rep Fish Aquat Sci 2190:1-36

Royal Commission on Environmental Pollution (2004) Twenty-fifth report. Turning the tide. Addressing the impact of fisheries on the marine environment. The Stationery Office, London

Sainsbury KJ, Campbell RA, Lindholm R, Whitelaw AW (1997) Experimental management of an Australian multispecies fishery: examining the possibility of trawl-induced habitat modification. In: Pikitch EK, Huppert DD, Sissenwine MP (eds) Global trends: fisheries management. American Fisheries Society, Bethesda, MD

Editorial responsibility: Gareth Harding (Contributing Editor), Dartmouth, Nova Scotia, Canada
Sanchez JA, Lasker HR (2003) Patterns of morphological integration in marine modular organisms: supra-module organization in branching octocoral colonies. Proc R Soc Lond B Biol Sci 270:2039-2044

SAS Institute (2002) JMP Statistics and graphs guide, Version 5. SAS, Cary, NC

Schwinghamer P, Gordon DC, Rowell TW, Prena J, McKeown DJ, Sonnichshen G, Guigné JY (1998) Effects of experimental otter trawling on surficial sediment properties of a sandy-bottom ecosystem on the Grand Banks of Newfoundland. Conserv Biol 12:1215-1222

Smith EP (2002) BACI design. In: El-Shaarawi AH, Piegorsch WW (eds) Encyclopedia of environmetrics. John Wiley \& Sons, Chichester

Thrush SF, Hewitt JE, Cummings VJ, Dayton PK (1995) The impact of habitat disturbance by scallop dredging on marine benthic communities: What can be predicted from the results of experiments? Mar Ecol Prog Ser 129:141-150

Underwood AJ (1992) Beyond BACI: the detection of environmental impacts on populations in the real, but variable, world. J Exp Mar Biol Ecol 161:145-178

Underwood AJ (1994) On beyond BACI: sampling designs that might reliably detect environmental disturbances. Ecol Appl 4:3-15

Van Dolah RF, Wendt PH, Nicholson N (1987) Effects of a research trawl on a hard-bottom assemblage of sponges and corals. Fish Res 5:39-54

Veale LO, Hill AS, Hawkins SJ, Brand AR (2000) Effects of long-term physical disturbance by commercial scallop fishing on subtidal epifaunal assemblages and habitats. Mar Biol 137:325-337

Wallace FW (1955) Roving fishermen. Canadian Fisherman. Gardenvale, Quebec

Wassenberg TJ, Dews G, Cook SD (2002) The impact of fish trawls on megabenthos (sponges) on the north-west shelf of Australia. Fish Res 58:141-151

Wentworth CK (1922) A scale of grade and class terms for clastic sediments. J Geol 30:377-392

Submitted: June 4, 2004; Accepted: June 27, 2005

Proofs received from author(s): December 1, 2005 